\title{
List of Thrips (Thysanoptera) recorded from Sri Lanka
}

\author{
Kalpana Tillekaratne ${ }^{1,4}$, Laurence A. Mound ${ }^{2}$, R. Zur Strassen ${ }^{3}$ and Jayanthi P. Edirisinghe ${ }^{4 *}$ \\ Postgraduate Institute of Science, University of Peradeniya, Peradeniya. \\ 2 Commonwealth Scientific and Industrial Research Organization (CSIRO) Entomology, Canberra, Australia. \\ 3 Forschungsinstitut Senckenberg, Frankfurt am Main, Germany. \\ 4 Department of Zoology, University of Peradeniya, Peradeniya.
}

Revised: 10 April 2007 ; Accepted: 20 April 2007

\begin{abstract}
This paper Presents list of the thrips (Insecta:Thysanoptera) of Sri Lanka which includes the species recorded in the country, from 1859 . Thrips documented locally come under 03 families; Aeolothripidae, Thripidae, Phlaeothripidae, 46 genera and 78 species. A brief description of the families and family groups are included. The distribution and host plants of the thrip species, where available are also indicated. Names of 15 recorded species listed are uncertain as they are known only from their original description and have not been recorded since.
\end{abstract}

Keywords: Crop pests, host records, thrips, Thysanoptera

\section{INTRODUCTION}

The insect order Thysanoptera is an important group of plant pests ${ }^{1}$ causing scarring and silvering of leaves, petals and fruits, premature flower-fall, pollen depletion, leaf shedding, and also leaf deformity and leaf galls. specifically, the thrips are important vectors of tospoviruses that cause serious crop losses around the world ${ }^{2-4}$. Some thrips species are predatory, and a few species have been used in the biological control of mites, scale insects and pest thrips ${ }^{5}$. A few phytophagous species have also been used in the biological control of weeds ${ }^{1}$. Thrips are increasingly being recognized as plant pollinators ${ }^{6}$ in plants as diverse as oil palm $^{7}$ and rainforest trees $^{8}$.

Worldwide, thrips comprise about 5500 recognized species in 750 genera and 9 families $^{9}$, and a checklist of these taxa can be accessed at: http://www.ento.csiro.au/ thysanoptera/worldthrips.html. The highest diversity of thrips occurs in the warm tropical parts of the world while the number of species in the colder regions is limited. The thrips of the Indian subcontinent have been extensively documented by Ananthakrishnan $\& \operatorname{Sen}^{10}$ and Bhatti ${ }^{11-13}$. However, in Sri Lanka thrips have scarcely been studied despite the significance of so many species to the agriculture and horticulture of this country. So far, the only published list of thrips of Sri Lanka (then Ceylon) is by Schmutz $^{14}$, which dates back to 1913 . It includes a total of only 43 species. Most of the thrips listed in Schmutz ${ }^{14}$ had been collected by Heinrich Uzel. He published the first extensive account of the Order Thysanoptera in 1895. Many years later, some of the fungus-feeding thrips of Sri Lanka were discussed in an account of nine genera of such thrips from the Oriental region ${ }^{15}$. More recently Oda et al ${ }^{16}$ recorded thrips from ornamental plants in Sri Lanka. Wijerathna ${ }^{17}$ listed 16 species of thrips from 28 crops along with many other insect pests from a wide variety of crops, compiled largely from unpublished records of the Department of Agriculture. The information on crop hosts ${ }^{17}$ has not been included as all the counter references could not be traced.

Host records and host plant relationships of thrips have become very important, especially in the recent times, owing to an increase in abundance and distribution of thrips on a variety of economic crops and on natural vegetation (Figures 1 \& 2). Adult thrips frequently rest on, and are collected from, plants on which they do not breed or feed. Therefore, in the absence of information on breeding many published records of "host plants" of thrips must be treated with caution.

Thrips differ from all other insects, both as adults and larvae, in having asymmetrical mouthparts where the right mandible is vestigial. Moreover, adults have a protrusible bladder at the apex of each tarsus and, when present, the wings have a marginal fringe of long cilia $^{6}$, which is very characteristic of thrips.

* Corresponding author 
The objective of this paper is to list the species of thrips recorded from Sri Lanka giving the reference to the first record of each species in the country. Some of the species listed from Sri Lanka are known only from their original, and often inadequate, descriptions, and the identity of some of these remain in doubt. The only relevant identification guides on the thrips of Sri Lanka are those on the fauna of the Indian subcontinent by Ananthakrishnan and $\operatorname{Sen}^{10}$. For species associated with crops, the most useful source of information is the CD-Rom Thrips ID, available from the Australian Centre for International Agricultural Research (ACIAR), Canberra, Australia. This is an electronic information and identification system to 180 species of pest thrips worldwide, including representatives of all families, and is illustrated with 1500 colour photomicrographs ${ }^{18}$. This present list is intended to form the basis for an ongoing field study on the diversity and ecology of thrips of Sri Lanka.

\section{List of thrips recorded from Sri Lanka}

Thysanoptera in Sri Lanka belongs to the three families Aeolothripidae, Thripidae and Phlaeothripidae. A total of 78 species of thrips belonging to 46 genera have been recorded. They are listed here initially under the two suborders Terebrantia and Tubilifera and thereafter under their respective family groups as recognized by Mound and Morris ${ }^{9}$. A short introduction to each family group is followed by the current valid species name. Each species name is followed by the reference to its original publication with synonyms. Comments are made of any doubtful species or host records given in previous publications. Host records and collection localities of species as given in the original publications are included, where available. The abbreviations for collection localities are as follows:

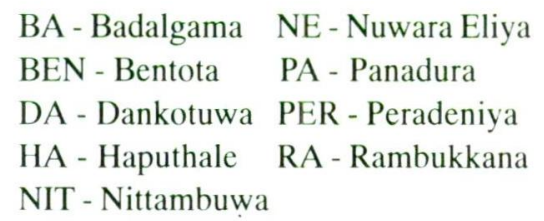

\section{Order Thysanoptera}

Two suborders of Thysanoptera are recognized. In the suborder Terebrantia females have a saw-like ovipositor, and in suborder Tubulifera females have a soft eversible ovipositor and the last abdominal segments form a tube. The suborder Terebrantia includes eight families, of which two are recorded from Sri Lanka, and suborder Tubulifera is represented by a single worldwide family with many species in Sri Lanka.

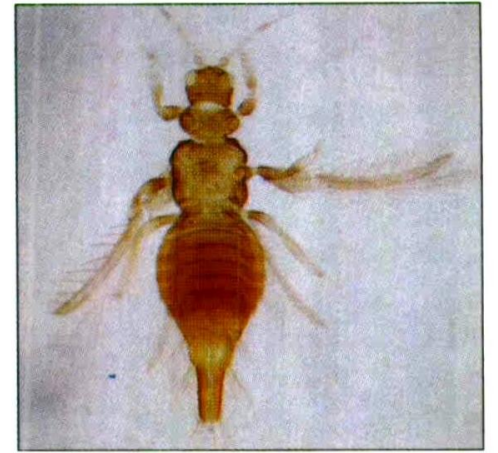

Figures 1: Slide mounted specimen of Panchaetothrips indicus

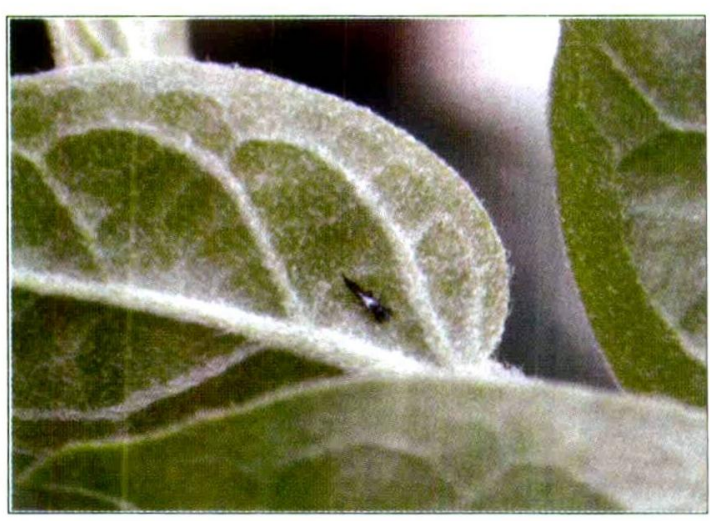

Figures 2: A Thrips on terminal leaves of Jasmine

\section{Suborder Terebrantia}

\section{Aeolothripidae}

The 190 recognized species in this family live mainly on flowers in temperate regions, while in the tropics several genera of predatory species live on leaves.

\section{Franklinothrips vespiformis (Crawford, 1909)}

Aeolothrips vespiformis Crawford, ${ }^{19}$ 1909: 109.

Host/collected from: Bougainvillea flowers (PER) ${ }^{16}$ Predatory on other thrips.

\section{Thripidae}

About 2000 species worldwide are included in this family, in which four subfamilies are now recognized.

\section{Thripidae - Panchaetothripinae}

About 125 species are recognized in this subfamily, all leaf feeding and with the exception of Caliothrips species, all breed on mature leaves. Wilson ${ }^{20}$ provided a taxonomic account of this group.

Caliothrips graminicola (Bagnall \& Cameron, 1932)

Hercothrips graminicola Bagnall \& Cameron, ${ }^{21}$ 1932: 417. 
Host/collected from: Recorded from grasses by $\mathrm{Kudo}^{22}$. This species also occurs in India, Australia and Sudan ${ }^{22}$.

\section{Caliothrips indicus (Bagnall, 1913)}

Heliothrips indicus Bagnall, ${ }^{23}$ 1913: 291.

It is known to be widespread on legumes in India.

\section{Copidothrips octarticulatus Schmutz, 1913}

Heliothrips (Parthenothrips) octarticulatus Schmutz, ${ }^{14}$ 1913: 993. Widespread, but not so common in the Old World tropics, recorded from Sri Lanka (PER) ${ }^{20}$.

\section{Helionothrips brunneipennis (Bagnall, 1915)}

Heliothrips brunneipennis Bagnall, ${ }^{24}$ 1915: 318.

This species is described originally from Sri Lanka.

\section{Heliothrips haemorrhoidalis (Bouché, 1833)}

Thrips haemorrhoidalis Bouché, ${ }^{25}$ 1833: 42.

Heliothrips (Heliothrips) haemorrhoidalis var. ceylonicus Schmutz, ${ }^{14}$ 1913:992.

Heliothrips ceylonicus Schmutz, ${ }^{14}$ 1913: 992.

Host/collected from: Codiaeum (BA) and Ficus benjamina $(\mathrm{DA})^{16}$.

It is a worldwide green house thrip species.

\section{Noathrips prakashi Bhatti, 1967}

Noathrips prakashi Bhatti, ${ }^{26}$ 1967: 9.

$\mathrm{Kudo}^{22}$ recorded this Indian species from Sri Lanka.

\section{Panchaetothrips indicus Bagnall, 1912}

Panchaetothrips indicus Bagnall, ${ }^{27}$ 1912: 258.

Host/collected from: Flowers of Dendrobium (PER) ${ }^{16}$. This species is considered a pest of turmeric in India.

\section{Parthenothrips dracaenae (Heeger, 1854)}

Heliothrips dracaenae Heeger, ${ }^{28}$ 1854: 365.

Host/collected from: Dracaena (NE) ${ }^{16}$.

This species is distributed around the world, often on leaves of decorative palms.

\section{Phibalothrips peringueyi Faure, 1925}

Reticulothrips peringueyi Faure, ${ }^{29}$ 1925: 145.

This species is recorded in Sri Lanka by Kudo ${ }^{22}$.

\section{Retithrips syriacus Mayet, 1890}

Thrips (Heliothrips) syriacus Mayet, ${ }^{30}$ 1890: 451. Host/collected from: Rose flowers (PA) ${ }^{16}$.

\section{Rhipiphorothrips cruentatus Hood, 1919}

Rhipiphorothrips cruentatus Hood, ${ }^{31}$ 1919: 94.
Rhipiphorothrips pulchellus Morgan, 1913

Rhipiphorothrips pulchellus Morgan, ${ }^{32}$ 1913: 17.

Retithrips bicolor Bagnall, ${ }^{23}$ 1913: 290.

A widespread pest of grapevines and several other plants in India, this species is recorded from Afganistan and the synonym indicated was from Sri Lanka.

Selenothrips rubrocinctus (Giard, 1901)

Physopus rubrocinctus Giard, ${ }^{33} 1901: 263$.

Heliothrips (Selenothrips) mendax Schmutz, ${ }^{14}$ 1913: 994 Host/collected from: Codiaeum (DA, BA), Solanaceae and wild flowers $(\mathrm{BA})^{16}$.

It is known to be a circum-tropical species.

\section{Tryphactothrips rutherfordi (Bagnall, 1915)}

Dinurothrips rutherfordi Bagnall, ${ }^{24}$ 1915: 319.

This species is known only from the original specimen that lacks antennae.

\section{Thripidae - Dendrothripinae}

Almost 100 species are recognized in this subfamily, all living on the leaves of higher plants.

\section{Pseudodendrothrips ornatissimus Schmutz, 1913}

Pseudodendrothrips ornatissimus Schmutz ${ }_{1}^{14}$ 1913: 999. This species is apparently associated in India with Artocarpus heterophyllus (E.Jak).

\section{Dendrothrips sexmaculatus Bagnall, 1916}

Dendrothrips sexmaculatus Bagnall, ${ }^{34}$ 1916: 401.

This species is described from Sri Lanka ${ }^{34}$ and is widespread in southern India. It is also known from South Africa.

\section{Thripidae-Thripinae}

At least 1700 species are recognized in this subfamily. They breed mostly on flowers or on leaves, with many also breeding on grasses, whilst a few are predatory or feed on ferns. This subfamily includes most of the serious thrips pests, including all the vectors of tospoviruses ${ }^{4}$.

\section{Anaphothrips sudanensis Trybom, 1911}

Anaphothrips sudanensis Trybom, ${ }^{35}$ 1911: 60. Neophysopus medioflavus Schmutz, ${ }^{14}$ 1913: 1017. This species is recorded from Sri Lanka by Schmutz ${ }^{14}$. This species is widespread in the tropics and subtropics and it is known to feed on grasses, cereals and sugar cane.

Bolacothrips striatopennatus Schmutz, 1913

Thrips striatopennatus Schmutz ${ }^{14}$ 1913: 1002. 
This species is recorded from Sri Lanka by Schmutz ${ }^{14}$. A widespread tropical species on grasses.

\section{Bregmatothrips brachycephalus (Shumsher, 1942)}

Neolimothrips brachycephalus Shumsher ${ }^{36}$ 1942: 118. Host/collected from: Grasses. Bhatti ${ }^{37}$ recorded this grassliving species from Sri Lanka.

Chaetanaphothrips signipennis (Bagnall, 1914)

Scirtothrips signipennis Bagnal, ${ }^{36}$ 1914: 22.

A species widespread around the world on Orchid leaves and sometimes is a pest of banana.

\section{Deuterobrachythrips lineatus Schmutz, 1913}

Deuterobrachythrips lineatus Schmutz, ${ }^{14}$ 1913: 997.

This genus and species is known only from the original and inadequate description.

\section{Frankliniella occidentalis (Pergande, 1895)}

Euthrips occidentalis Pergande, ${ }^{39}$ 1895: 392.

Host/collected from: Flowers of Alstroemeria (NE) and Gypsophila (NE) ${ }^{16}$. This highly polyphagous worldwide pest species is a vector of tospoviruses.

\section{Frankliniella schultzei (Trybom, 1910)}

Physopus schultzei Trybom, ${ }^{41}$ 1910: 151.

Frankliniella sulphurea Schmutz, ${ }^{14}$ 1913: 1019.

Host/collected from: Flowers of Bougainvillea, Canna, Dailia (PER), Lantana (BA) ${ }^{\mathrm{th}}$ and carnation ${ }^{4 !}$.

It is a widespread pest species and a vector of tospoviruses.

\section{Megalurothrips distalis (Karny, 1913)}

Taeniothrips distalis Karny, ${ }^{+2}$ 1913: 122.

Host/collected from: Canna and white clover (NE) ${ }^{16}$.

All species of Megalurothrips are known to breed on flowers of Fabaceae, although adults can be found sometimes on other flowers, such as Canna.

\section{Megalurothrips typicus Bagnall, 1915}

Megalurothrips typicus Bagnall, ${ }^{43}$ 1915: 590.

Host/collected from: Flowers of Glyricidia (DA) ${ }^{16}$.

\section{Megalurothrips usitatus (Bagnall, 1913)}

Physothrips usitatus Bagnall, ${ }^{23}$ 1913: 293.

Frankliniella nigricornis Schmutz, ${ }^{i \downarrow}$ 1913: 1020.

Frankliniella obscuricornis Schmutz, ${ }^{14}$ 1913:1022.

Frankliniella vitata Schmutz, ${ }^{+\dagger}$ 1913: 1023.

Host/collected from: Coffea (RA), Pueraria (BA) and Rosa $(\mathrm{PER})^{1 \mathrm{th}}$.

This species is known to breed on flowers of many Fabaceae including crops such as pigeon pea.

\section{Microcephalothrips abdominalis (Crawford, 1910)}

Thrips abdominalis Crawford, ${ }^{44}$ 1910: 157

Host/collected from: Canna, Compositae (PER), Solanaceae (NIT) and Dendrobium (PA) (RA) ${ }^{\text {th. }}$.

It is known to breed on flowers of several Asteraceae including sun flower.

\section{Neohydatothrips samayunkur Kudo, 1995}

Hydatothrips (Neohydatothrips) samayunkur Kudo, ${ }^{45}$ 1995: 169. Host/collected from: Flowers of Tagetes sp. (Marigold) (PA) ${ }^{16}$. The species is widely recorded on flowers of marigold.

\section{Sciothrips cardamomi (Ramakrishna, 1935)}

Taeniothrips cardamomi Ramakrishna Ayyar, ${ }^{40}$ 1935: 357. It is known at times to be a serious pest of cardamom leaves, in India.

\section{Scirtothrips dorsalis Hood, 1919}

Scirtothrips dorsalis Hood, ${ }^{34}$ 1919: 90.

Host/collected from: Arachis (PA), Bougainvillea (PER) and Solanaceae (BA) ${ }^{16}$.

It is a widespread leaf feeding pest species of the world.

\section{Stenchaetothrips biformis (Bagnall, 1913)}

Bagnallia biformis Bagnall, ${ }^{47}$ 1913: 237.

Host/collected from: Gypsophila (NE) ${ }^{16}$.

It is the oriental rice thrips. It is also listed by Wijerathna ${ }^{17}$ on onion and paddy.

\section{Thrips coloratus (Schmutz, 1913)}

Thrips coloratus Schmutz, ${ }^{14}$ 1913:1013.

This species is recorded from Sri Lanka by Schmutz ${ }^{14}$, as a flower feeding species. It is widespread across Asia to Australia.

\section{Thrips flavus Schrank, 1776}

Thrips flavus Schrank, ${ }^{48} 1776: 31$.

Host/collected from: White clover (NE) ${ }^{16}$.

It is widespread from Europe to Taiwan on many different flowers.

\section{Thrips florum Schmutz, 1913}

Thrips florum Schmutz, ${ }^{14}$ 1913: 1003 .

Thrips parvus Schmutz, ${ }^{14}$ 1913:1004.

Thrips magnipes Schmutz, ${ }^{14}$ 1913:1006.

Thrips rhodamniae Schmutz, ${ }^{14}$ 1913:1008.

Thrips pallida Schmutz ${ }^{14}$ 1913:1015.

Thrips peradenyae Schmutz, ${ }^{14}$ 1913:1015.

It is a widespread polyphagous species worldover. 


\section{Thrips hawaiiensis (Morgan, 1913)}

Euthrips hawaiiensis Morgan, ${ }^{32}$ 1913: 3. Thrips sulphurea Schmutz, ${ }^{14}$ 1913: 1011. Thrips nigriflava Schmutz, ${ }^{14}$ 1913: 1012.

Host/collected from: Adenium, Glyricidea (DA), Pueraria, Solanaceae (BA), Bougainvillea, Canna, Dahlia, Hibiscus, rose (PER), Dendrobium and Coffea (RA) ${ }^{16}$. This species is closely related to Thrips florum and is simillarly widespread and polyphagous.

\section{Thrips longalatus Schmutz, 1913}

Thrips longalatus Schmutz, ${ }^{14}$ 1913: 1009.

It is a flower feeder known only from Sri Lanka ${ }^{11}$.

\section{Thrips palmi Karny, 1925}

Thrips palmi Karny, ${ }^{49} 1925: 10$.

Host/collected from: Arachis, Dendrobium, cucumber (PA), Bougainvillea and Zinnia (PER) ${ }^{16}$.

It is a South-East Asian species and an important crop pest in many tropical countries.

\section{Thrips simplex (Morison, 1930)}

Physothrips simplex Morison, ${ }^{50}$ 1930: 12.

Host/collected from: Canna (NE) Gladiolus (HA) ${ }^{16}$.

This species has a worldwide distribution and damages flowers and leaves of Gladiolus.

\section{Thrips tabaci Lindeman, 1889}

Thrips tabaci Lindeman, ${ }^{51}$ 1889: 61.

Host/collected from: Carnation ${ }^{41}$, Gerbera, Limonium, white clover (NE) ${ }^{16}$.

It is a highly polyphagous worldwide pest.

\section{Suborder Tubulifera}

Only a single family with two subfamilies is recognized in this Suborder.

\section{Phlaeothripidae - Idolothripinae}

There are about 600 species worldwide in this subfamily, and all of them feed by ingesting whole fungal spores. Mound \& Palmer ${ }^{52}$ provide an account of the genera in this group, and Mound \& Palmer ${ }^{15}$ provide keys to some species.

\section{Bactrothrips idolomorphus (Karny, 1919)}

Bactridothrips idolomorphus Karny, ${ }^{53}$ 1919: 117.

Bactridothrips serraticornis Bagnall, ${ }^{54}$ 1921: 397.

It is recorded from Sri Lanka by Karny ${ }^{53}$ and is widespread across South-East Asia in association with hanging dead leaves.
Diaphorothrips unguipes Karny, 1920

Diaphorothrips unguipes Karny, ${ }^{55} 1920: 186$.

Host/collected from: Dead twigs (BEN) ${ }^{15}$.

This species is widespread across India.

\section{Dinothrips spinosus (Schmutz, 1913)}

Ischyrothrips spinosus Schmutz, ${ }^{14}$ 1913: 1078.

Host/collected from: Dead branches in rainforests ${ }^{15}$.

This species is widespread across South-East Asia.

\section{Dinothrips sumatrensi Bagnall, 1908}

Dinothrips sumatrensis Bagnall, ${ }^{56}$ 1908: 191.

Dinothrips furcifer Schmutz, ${ }^{14}$ 1913:1026.

Host/collected from: Dead branches ${ }^{15}$.

This species is wide spread across South-East Asia.

\section{Elaphrothrips denticollis (Bagnall, 1909)}

Dicaiothrips denticollis Bagnall, ${ }^{57}$ 1909: 527.

Host/collected from: Dead leaves and branches (PER) ${ }^{15}$. This species is widespread across South-East Asia.

\section{Elaphrothrips greeni (Bagnall, 1914)}

Dicaiothrips greeni Bagnall, ${ }^{58}$ 1914: 289.

Host/collected from: Dead leaves and branches (PER) ${ }^{15}$. It is widespread in Southern India.

\section{Elaphrothrips malayensis (Bagnall, 1909)}

Dicaiothrips malayensis Bagnall, ${ }^{57}$ 1909: 525.

Dicaiothrips bruneitarsis Schmutz, ${ }^{14}$ 1913: 1070.

Dicaiothrips bruneitarsis var levis, Schmutz, ${ }^{14}$ 1913: 1072.

Elaphrothrips coronatus Bagnall, ${ }^{59}$ 1934: 631.

Host/collected from: Dead leaves and branches ${ }^{15}$.

It is widespread across South East Asia.

\section{Elaphrothrips procer (Schmutz, 1913)}

Dicaiothrips procer Schmutz, ${ }^{14}$ 1913: 1063.

Dicaiothrips novus Schmutz, ${ }^{14}$ 1913: 1066.

Dicaiothrips dallatorensis Schmutz, ${ }^{14}$ 1913: 1067.

Dicaiothrips proximus Bagnall, ${ }^{58}$ 1914: 289.

Elaphrothrips achaetus Bagnall, ${ }^{59}$ 1934: 633.

Elaphrothrips approximatus Bagnall, ${ }^{59}$ 1934: 635.

Host/collected from: Dead leaves and branches ${ }^{15}$.

It is widespread in Southern India.

\section{Ethirothrips angusticornis (Bagnall, 1924)}

Mesothrips angusticornis Bagnall, ${ }^{60}$ 1924: 638.

Described from Sri Lanka by Bagnall ${ }^{60}$ but inadvertently omitted from the world checklist by Mound and Palmer ${ }^{52}$. 


\section{Ethirothrips indicus Bagnall, 1912}

Mesothrips indicus Bagnall, ${ }^{61} 1921: 365$.

Host/collected from: Lantana flowers (NIT) ${ }^{16}$.

This species is known to feed by imbibing fungal spores.

Ethirothrips obscurus (Schmutz, 1913)

Ischyrothrips obscurus Schmutz, ${ }^{14}$ 1913: 1074.

Recorded from Sri Lanka by Schmutz ${ }^{14}$.

This species is widespread in Southern India on dead branches and is also recorded from Africa and Cuba.

\section{Ethirothrips stenomelas (Walker, 1859)}

Phlaeothrips stenomelas Walker, ${ }^{62}$ 1859: 224.

Ischyrothrips niger Schmutz, ${ }^{14}$ 1913: 1080.

Recorded from Sri Lanka by Schmutz ${ }^{14}$ the species is widely distributed around the tropics.

\section{Ethirothrips watsoni (Karny, 1920)}

Gynaikothrips watsoni Karny, ${ }^{53} 1920: 106$.

Bhatti ${ }^{63}$ designated a lectotype for this species that was described from Sri Lanka.

\section{Ischyrothrips crassus Schmutz, 1913}

Ischyrothrips crassus Schmutz, ${ }^{14} 1913: 1076$.

This species is known only from the original female.

\section{Mecynothrips simplex Bagnall, 1912}

Mecynothrips simplex Bagnall, ${ }^{64}$ 1912: 216.

Kleothrips gigans Schmutz, ${ }^{14}$ 1913: 058.

Dracothrips ceylonicus Bagnall, ${ }^{58} 1914: 290$.

It is recorded from Sri Lanka by Schmutz ${ }^{14}$ and is wide spread in South-East Asia.

\section{Neosomerinthothrips affinis (Bagnall, 1921)}

Coenurothrips affinis Bagnall, ${ }^{61} 1921: 361$.

This species is known only from the original specimen from Sri Lanka.

\section{Neosomerinthothrips fructuum Schmutz, 1913}

Nesomerinthothrips fructuum Schmutz, ${ }^{14} 1913: 1052$.

Oedemothrips ceylonicus Karny, ${ }^{65}$ 1925: 137.

Host/collected from: Ornamental flowers ${ }^{16}$, presumably based on dispersing adults and not on a breeding population. It is known to be a common species on dead twigs and branches and on palm fronds.

\section{Phlaeothripidae - Phlaeothripinae}

This subfamily includes about 2500 described species in 350 genera. At least $50 \%$ of these species feed on fungal hyphae found on dead branches and leaf litter, but a large number of Oriental species are associated with galled leaves. One group of species is abundant on flowers of grasses and Asteraceae, and a few species are predatory on other arthropods.

\section{Aleurodothrips fasciapennis (Franklin, 1908)}

Cryptothrips fasciapennis Franklin, ${ }^{66} 1908: 727$.

Recorded from Sri Lanka by Franklin ${ }^{66}$.

It is known to be a widespread predator of scale insects on various trees across South-East Asia to Australia

\section{Androthrips flavipes (Schmutz, 1913)}

Androthrips flavipes Schmutz, ${ }^{14}$ 1913: 1031.

Androthrips flavipes Bagnall, ${ }^{38}$ 1914: 27.

Recorded from Sri Lanka Schmutz ${ }^{14}$.

It is known to be a predator within leaf-galls induced by other thrips.

\section{Chromatothrips annulicornis (Schmutz, 1913)}

Chromatothrips annulicornis Schmutz, ${ }^{14}$ 1913: 1045. Known only from the original and inadequate description. Nothing further is known of this genus nor of its three species from Sir Lanka.

\section{Chromatothrips fasciatus Schmutz, 1913}

Chromatothrips fasciatus Schmutzs, ${ }^{14}$ 1913: 1044.

This species is known only from the original and inadequate description.

\section{Chromatothrips plantaginis Schmutz, 1913}

Chromatothrips plantaginis Schmutz, ${ }^{14}$ 1913: 1047.

This species is known only from the original and inadequate description.

\section{Ecacanthothrips tibialis (Ashmead, 1905)}

Idolothrips tibialis Ashmead, ${ }^{67} 1905.20$.

Ormothrips steinsky Schmutz, ${ }^{14} 1913: 1028$ (Synomized with sanguineus by Ananthakrishnan,1961:275).

Host/collected from: Dead bark ${ }^{15}$.

A common and highly polymorphic species that is widespread on dead branches from Eastern Africa to Australia.

\section{Eumorphothrips albicornis Schmutz, 1913}

Eumorphothrips albicornis Schmutz, ${ }^{14}$ 1913: 1050.

It is known only from the original and inadequate description.

\section{Gigantothrips schenklingi (Karny)}

Idolothrips schenklingi Karny, ${ }^{55}$ 1920: 189.

It is known only from the original and inadequate description. 


\section{Gigantothrips tibialis Bagnall, 1921}

Gigantothrips tibialis Bagnall, ${ }^{61}$ 1921:364.

This species is recorded from Sri Lanka by Bagnall ${ }^{61}$. It is a widespread galling species in India.

\section{Haplothrips ceylonicus Schmutz,1913}

Haplothrips ceylonicus Schmutz, ${ }^{14}$ 1913: 1038. Host/collected from: Cassipourea sp. \& Crotolaria striata $\left(\right.$ PER ${ }^{68}$. Flowers of Saraca (PER) ${ }^{16}$.

This species was originally described from Sri Lanka and is widespread in South-East Asia.

\section{Haplothrips (Haplothrips) ganglbaueri Schmutz, 1913}

Haplothrips ganglbaueri Schmutz, ${ }^{14}$ 1913: 1034.

Host/collected from: Rice flowers (PER) ${ }^{68}$. Rice panicles ${ }^{69}$. This species was originally recorded from Sri Lanka and is widespread in South-East Asia.

\section{Haplothrips (Haplothrips) gowdeyi (Franklin, 1908)}

Anthothrips gowdeyi Franklin, ${ }^{66}$ 1908: 724.

Haplothrips soror Schmutz, ${ }^{14}$ 1913: 1036(PER) ${ }^{68}$.

Haplothrips sororcula Schmutz, ${ }^{14}$ 1913: 1036 (PER) ${ }^{68}$.

Host/collected from: Flowers of Canna and Crotalaria striata (PER) ${ }^{68}$. Rose flowers (PER) ${ }^{16}$.

This is a widespread tropical species.

\section{Haplothrips (Haplothrips) terminalis Schmutz, 1913}

Haplothrips terminalis Schmutz, ${ }^{14}$ 1913: 1033.

It is not recorded since its original description.

\section{Liothrips floridensis (Watson)}

Cryptothrips floridensisis Watson, ${ }^{70}$ 1913:145

This species is known to breed on young leaves of Cinnamomum camphor. It is also known from Florida, Japan and Taiwan.

\section{Liothrips (Liothrips) karnyi (Bagnall, 1913)}

Gynaikothrips karnyi Bagnall, ${ }^{38}$ 1914: 28.

It is recorded from Sri Lanka by Bagnall ${ }^{38}$.

\section{Liothrips (Liothrips) mirabilis Schmutz, 1913}

Gynaikothrips mirabilis Schmutz, ${ }^{14}$ 1913: 1041. It is not recorded since its original description.

Liothrips (Liothrips) tropicus (Schmutz, 1910)
Smerinthothrips tropicus Schmutz, ${ }^{71}$ 1910: 342.

It is not recorded since its original description.

\section{Liothrips (Liothrips) vaneeckei Priesner, 1920}

Liothrips vaneeckei Priesner, ${ }^{72}$ 1920: 211.

Host/collected from: The orchid Vanda roxbughi imported from Ceylon to the US ${ }^{73}$.

\section{Teuchothrips brevis (Bagnall, 1924)}

Mesothrips brevis Bagnall, ${ }^{60}$ 1924: 636.

It is not recorded since its original description.

\section{Teuchothrips longus (Schmutz, 1913)}

Mesothrips longus Schmutz, ${ }^{14}$ 1913: 1054.

Mesothrips pavethae Schmutz, ${ }^{14}$ 1913: 1055.

It is not recorded since its original description.

\section{Trichinothrips breviceps (Bagnall, 1926)}

Trichaplothrips breviceps Bagnall, ${ }^{73}$ 1926: 550.

This species is recorded from Sri Lanka by Bagnall ${ }^{74}$.

It is known to be widespread but not common in South-

East Asia. It is possibly a predator.

\section{Acknowledgement}

The National Science Foundation (NSF) of Sri Lanka is acknowledged for the grant awarded to the last author for the study on the "Taxonomy and ecology of thrips of Sri Lanka".

\section{References}

1. Morse J.G. \& Hoddle M.S. (2005). Invasion biology of thrips. Annual Review of Entomology 51: 67-89.

2. Lewis T. (1973). Thrips, Their Biology, Ecology and Economic Importance. pp.349. Academic Press, London and New York.

3. Lewis T. (1997). Thrips as Crop Pests. pp.740. CAB International, Wallingford, England.

4. Mound L.A. (1996). The Thysanoptera vector species of tospoviruses. Acta horticulturae 431: 298-309.

5. Mound L.A. \& Reynaud P. (2005). Franklinothrips; a pantropical Thysanoptera genus of ant-mimicking obligate predators (Aeolothripidae). Zootaxa 864: 1-16.

6. Mound L.A. (2004). Thysanoptera-diversity and interactions. Annual Review of Entomology 50: 247-269.

7. Syed R.A. (1979). Studies on oil palm pollination by insects. Bulletin of Entomological Research 69: 213-224.

Note: Since information on the following 6 species (Schmutz) ${ }^{14}$ is not available to the authors they are not included in the list. (Tryphactothrips octarticulata, Cercothrips tibialis, Taeniothrips vitata, Taeniothrips nigricornis, Taeniothrips usitatus, Cryptothrips longus) 
8. Zeregd N.J.C., Mound L.A. \& Weiblen G.D. (2004). Pollination in the New Guinea endemic Antiaropsis decipiens (Moraceae) is mediated by a new species of thrips, Thrips antiaropsidis sp. nov. (Thysanoptera: Thripidae). International Journal of Plant Sciences 165: 1017-1026.

9. Mound L.A. \& Morris D.C. (2003). The morphological background to Thysanoptera phylogeny. Entomologische Abhandlungen 61: 151-153.

10. Ananthakrishnan T.N. \& Sen S. (1980). Taxonomy of Indian Thysanoptera. Zoological Survey of India (Handbook Series) 1: 1-234.

11. Bhatti J.S. (1990). Catalogue of Insects of the Order Terebrantia from the Indian subregion. Zoology 2: 205-352.

12. Bhatti J.S. (2004a). T.N. Ananthakrishnan's entomological publications between 1947 and 2004. Bibliography with annotations. Thysanoptera 2004: 1-84:

13. Bhatti J.S. (2004b). T.N. Ananthakrishnan's taxa of Thysanoptera 1950 to 1980. Thysanoptera 2004: 85-181.

14. Schmutz K. (1913). Zur Kentniss der Thysanopterenfauna von Ceylon. Sitzungsber Akademie der Wissenschaften, Wien 122: 991-1089.

15. Palmer J.M. \& Mound L.A. (1978). Nine genera of fungus-feeding Phlacothripidae (Thysanoptera) from the Oriental Region. Bulletin of the British Museum (Natural History) Entomology 37:153-215.

16. Oda Y., Kahawatta U.C., Rajapaksha P., \& Rajapaksha H. (1997). Thrips collected in Sri Lanka. Research Bulletin of the Plant Protection Service, Japan 33: 71-73.

17. Wijerathna P.M. (1999). Insects feeding on plants in Sri Lanka. pp. 171. Plant Genetic Resource Centre, Gannoruwa, Peradeniya.

18. Moritz G., Morris D.C. \& Mound L.A. (2001). ThripsID - Pest thrips of the world. An interactive identification and information system. Cd-rom published for ACIAR by CSIRO Publishing, Melbourne.

19. Crawford D.L. (1909). Some Thysanoptera of Mexico and the South. 1. Pomona College Journal of Entomology and' Zoology 1: 109-119.

20. Wiison T.H. (1975). A monograph of the subfamily Panchaetothripinae (Thysanoptera: Thripidae). Memoirs of the American Entomological Institute 23: 1-354.

21. Bagnall R.S. \& Cameron W.P.L. (1932). Description of two species of Hercothrips injurious to cotton in British Sudan and of an allied species of grass. Annals and Magazine of Natural History (10) 10: 412.

22. Kudo I. (1979). Some panchaetothripine Thysanoptera from Southeast Asia. Oriental Insects 13: 345-355.

23. Bagnall R.S. (1913). Brief descriptions of new Thysanoptera. I. Annals and Magazine of Natural History (8) 12: 290-299.

24. Bagnall R.S. (1915). Bricf descriptions of new Thysanoptera V. Annals and Magazine of Natural History (8) $15: 315-324$

25. Bouché P.F. (1833). Naturgeschichte der schadlichen und nutzlichen Garten-Insekten und die bewahrtesten Mittel zur Vertilgung der Ersteren. pp. 176. Berlin.
26. Bhatti J.S. (1967). Thysanoptera Nova Indica. pp. 24. New Delhi: Published privately.

27. Bagnall R.S. (1912). On a new genus of Indian thrips (Thysanoptera) injurious to turmeric. Records of the Indian Museum 7: 257-260.

28. Heeger E. (1854). Beiträge zur Naturgeschichte der Insekten Osterreichs. Sitzungsberichte Akademie der Wissenschaften Wien Mathematisch-Naturwissenschaftliche Klasse Abt.I 14: 365-373.

29. Faure J.C. (1925). A new genus and five new species of South African Thysanoptera. South African Journal of Natural History 5: 143-166.

30. Mayet V. (1890). Les Insectes de la Vigne. Biblioteque du Progres Agricole et Viticole 448-453.

31. Hood J.D. (1919). On some new Thysanoptera from southern India. Insecutor Inscit menstr 7: 90-103.

32. Morgan A.C. (1913). New genera and specics of Thysanoptera, with notes on distribution and food plants. Proceedings of the United States National Museum 46: 1-55.

33. Giard A. (1901). Sur un Thrips (Physopus rubrocincta nov. sp.) nuisable au Cacaoyer. Bulletin de la Société Entomologique de France, 1901: 263-265.

34. Bagnall R.S. (1916). Brief descriptions of new Thysanoptera VIII. Annals and Magazine of Natural History (8) 17: 397-412.

35. Trybom F. (1911). Physapoden aus Agypten und dem Sudan In: Results of the Swedish Zoological Expedition to Egypt and the White Nile (1900-1901) under the direction of L.A.Jagerskiold, Pt IV. pp. 16.

36. Shumsher S. (1942). A contribution to our knowledge of Indian Thysanoptera. Indian Journal of Entomology 4: 111-135.

37. Bhatti J.S. (1984). A remarkable Bregmatothrips-like new genus from Africa, with a review of Bregmatothrips Hood and Plutonothrips Priesner. Annals of Entomology 2: 83-97.

38. Bagnall R.S. (1914). Brief descriptions of new Thysanoptera Il. Annals and Magazine of Natural History (8) 13:22-31.

39. Pergande T. (1895). Observations on certain Thripidae. Insect Life 7: 390-395.

40. Trybom F. (1910). Physapoda. Schultze, Zoologische und anthropologische Ergebnisse einer Forschungsreise im westlichen and zentralen Sudafrika, (1903-1905). Denkschr. Med.-Naturwiss. Ges. Jena 16: 147-174.

41. De Silva P.S.Y., Vithanage K.D. \& Kelaniyangoda D.B. (2005). Import Risk Analysis (IRA) of carnations. Annals of the Sri Lanka Department of Agriculture 7: 67-86.

42. Karny H. (1913). Thysanoptera von Japan. Archiv für Naturgeschichte 79: 122-128.

43. Bagnall R.S. (1915). Brief descriptions of new Thysanoptera. VI. Annals and Magazine of Natural History (8) 15: 588-597.

44. Crawford D.L. (1910). Thysanoptera of Mexico and the South 11. Pomona College Journa! of Entomology and Zoology 2: 153-170. 
45. Kudô I. (1995). A new species of Hydatothrips (Thysanoptera: Terebrantia: Thripidae) on marigold in Japan and the United States. Applied Entomology and Zoology 30 (1): 169-176.

46. Ramakrishna Ayyar T.V. (1935). A new species of Thysanoptera from S. India (Taeniothrips cardamomi) Bulletin of entomological Research 26:357-358.

47. Bagnall R.S. (1913). Further notes on new and rare British Thysanoptera (Terebrantia) with descriptions of new species. Journal of Economic Biology 8: 231-240.

48. Schrank F.P. (1776). Beitrage zur Naturgeschichte 1-137.

49. Karny H. (1925). Die an Tabak auf Java und Sumatra angetoffenen Blasenfusser (Thysanoptera). Bulletin van het deli proefstation te Medan 23: 1-55.

50. Morison G.D. (1930). On a collection of Thysanoptera from South Australia. Bulletin of Entomologicla Research 21: $9-14$

51. Lindeman K. (1889). Die schadlichsten Insekten des Tabak in Bassarabien. Bulletin de la Societe Imperiale des Naturalistes de Moscou 1: 9-77.

52. Mound L.A. \& Palmer J.M. (1983). The generic and tribal classification of spore-feeding Thysanoptera (Phlaeothripidae: Idolothripinae). Bulletin of the British Museum (Natural History). Entomology 46: 1-174.

53. Karny H. (1919). Synopsis der Megathripidae (Thysanoptera). Zeitschrift für Entomologie 1 (1917): 105 110: 113-118.

54. Bagnall R.S. (1921). Brief descriptions of new Thysanoptera XII. Annals and Magazine of Natural History 8(9): 393-400.

55. Karny H. (1920), Die exotischen Tubiliferen (Thysanopteran) des Deutschen Entomologischen Meseums (Berlin-Dablem). Entomologische Mitteilungen 9: 88-94, 104-111, 186-191.

56. Bagnall R.S. (1908). On some new genera and species of Thysanoptera. Transactions of the Natural History Society of Northumberland 3: 183-217.

57. Bagnall R.S. (1909). On some new and little known exotic Thysanoptera. Transactions of the Natural History Society of Northumberland 3:524-540.

58. Bagnall R.S. (1914). Brief descriptions of new Thysanoptera III. Annals and Magazine of Natural History 13(8): 287-297.
59. Bagnall R.S. (1934). Contribution towards the knowledge of the Thysanopterous genus Elaphothrips Buffa.I Annals and Magazine of Natural History (10) 13: 627-636.

60. Bagnall R.S. (1924). Brief descriptions of new Thysanoptera XIV. Annals and Magazine of Natural History (9) 14: 625-640.

61. Bagnall R.S. (1921). Brief descriptions of new Thysanoptera XI. Annals and Magazine of Natural History 7(9): 355-368.

62. Walker F. (1859). Characters of some apparently undescribed Ceylon insects. Annals and Magazine of Natural History 4(3): 217-224.

63. Bhatti J.S. (1993). List of world genera of the Order Tubulifera (Insecta). Zoology 3: 241-271.

64. Bagnall R.S. (1912). Priliminary descriptions of three new species of Thysanoptera Annals and Magazine of Natural History 9(8): 214-217.

65. Karny H. (1925). On some tropical Thysanoptera. Bulletin of Entomological Research 16: 125-142.

66. Franklin H.J. (1908). On a collection of Thysanopterous insects from Barbados and St. Vincent Islands. Proceedings of the United States National Museum 33: 715-730.

67. Ashmead W.H. (1905). A new thrips from the Philippine Islands. Entomology News 16: 20.

68. Pitkin B.R. (1976). A revision of the Indian species of Haplothrips and related genera (Thysanoptera: Phlaeothripidae). Bulletin of the British Museum (Natural History) Entomology 34 (4):223-280.

69. Kobayashi T. \& Nugaliyaddae L. (1988). The damage of rice panicles caused by insect pests in Sri Lanka. Japan Agricultural Research Quarterly 21 (4): 314-322.

70. Watson J.R.(1913). New Thysanoptera from Florida. Entomological News 24:145-148.

71. Schmutz K. (1910). Zur Kenntnis einiger neuen Thysanopterengenera (Tubulifera). Annalen des Naturhistorischen Museums, Wien 23: 273-281; 342-347.

72. Priesner H. (1920). Ein neuer Liothrips (Uzel) (Order. Thysanopteren) aus den Niederlanden. Zoologische Mededeelingen 5: 211-212.

73. Schopp and Doucette Ch.F. (1932). Liothrips vaneeckei Priesner,a recently discovered pest of lily bulbs. Journal of Economic Entomology 25 (5):211-212.

74. Bagnall R.S. (1926). Brief descriptions of new Thysanoptera. XVI. Annals and Magazine of Natural History (9) 18: 545-560. 